\title{
The Domestic Turn: Business Process Outsourcing and the Growing Automation of Kenyan Organisations
}

\section{Laura Mann \& Mark Graham}

To cite this article: Laura Mann \& Mark Graham (2016) The Domestic Turn: Business Process Outsourcing and the Growing Automation of Kenyan Organisations, The Journal of Development Studies, 52:4, 530-548, DOI: 10.1080/00220388.2015.1126251

To link to this article: http://dx.doi.org/10.1080/00220388.2015.1126251

曲 Published online: 22 Mar 2016.

Submit your article to this journal $₫$

Џ Article views: 80

Q View related articles $\square$

View Crossmark data ¿ 


\title{
The Domestic Turn: Business Process Outsourcing and the Growing Automation of Kenyan Organisations
}

\author{
LAURA MANN* \& MARK GRAHAM** \\ *African Studies Centre, Leiden, Netherlands, ${ }^{*}$ Oxford Internet Institute and School of Geography and the Environment, \\ University of Oxford, Oxford, United Kingdom
}

\begin{abstract}
After observing the growth of the Indian and Filipino Business Process Outsourcing (BPO) sectors, Kenyan policy-makers and managers made substantial investments in international internet infrastructure and BPO marketing campaigns. While observers continue to discuss the sector in terms of its international work opportunities, in recent years the sector has increasingly focused on contracts sourced from Kenyan and other East African clients. The government has also refocused efforts on attracting international BPO companies. This domestic turn signals both the difficulties of gaining access to overseas work due to the power of incumbents and the increasing use of the internet and ICT-enabled automation within Kenyan organisations. In effect, better connectivity has enabled a two-way globalisation of services: Kenyan BPO companies can access international work opportunities but connectivity has also contributed to the inflow of international business practices into Kenya. The conclusion examines what these shifts might entail for the sector and its workers in future.
\end{abstract}

\section{Introduction}

Business Process Outsourcing (BPO) can loosely be described as service work contracted out to a third party. The term encompasses a range of activities that include customer service work, data entry, transcription, digitisation, financial accounting, auditing and other higher value-knowledge processing such as content development, animation, legal services, engineering design and data analytics. The BPO sector first emerged in Northern economies in response to deregulation and competitive pressures inducing organisations to restructure, increase efficiencies and maximise shareholder value (Batt \& Moynihan, 2002; Davis, 2009). Work tasks that once took place within firms came to be standardised and outsourced to outside organisations, often using information and communication technologies (ICTs). Work was first moved to lower wage areas within national economies (Taylor \& Bain, 2008) but by the early 2000s, changing communication capacities had allowed such work to be offshored to countries such as India, the Philippines and China, effectively creating a 'global' ' marketplace for services (Dicken, 2003; Bryson, 2007; Malecki \& Moriset, 2008). The increasing geographical spread of BPO has resulted both from pressures to reduce costs and from desires by multinational companies (MNCs) to spread risk across markets (Kleibert, 2014).

BPO has been seen to represent very different facets of economic globalisations. On the one hand, it has been described as offering potential developmental benefits, allowing developing countries to leapfrog industrialisation, acquire new skills and capital, and participate in a flatter and more frictionless global economy (Dossani \& Kenney, 2007; Friedman, 2006). Fernandez-Stark, Bamber, and

Correspondence Address: 6.19, Connaught House, London School of Economics and Political Science, Houghton Street, London, WC2A 2AE, UK. Email: L.E.Mann@1se.ac.uk

The authors thank Linnet Taylor for helping to understand this aspect. 
Gereffi (2011, p. 1) thus write, 'the industry provides a clear illustration of how globalisation has provided opportunities for both employment and business formation in developing countries'. However, others have voiced more cautious assessments, stressing that benefits are 'uncertain and contingent' (Levy, 2005, p. 691) and that the globalisation of services is likely to benefit more highly skilled groups while weakening the security, economic prospects and bargaining power of less skilled workers (Held, 1999). Anxieties about BPO are particularly pronounced in relation to developed economies where fears of job losses dominate discussions.

Since 2004, Kenyan policy-makers and businesspeople have wanted a share of the market. Many hoped the 2009 arrival of fibre optic internet cables into East Africa would allow these economies to break their dependence on primary commodity exports and use the affordances of better internet connectivity to transition into tertiary and quaternary service sector exports (Graham \& Mann, 2013). The original vision for the BPO sector in Kenya was therefore export oriented, Kenyan owned and oriented towards the creation of jobs (Graham, Andersen, \& Mann, 2015). Estimates released by the Government of Kenya $(2007 \mathrm{a}, \mathrm{b})$ predicted the sector would create 20,000 direct BPO jobs and contribute 10 billion Kenyan shillings to GDP (approximately 114 million USD).

Few connected the deeper penetration of high speed internet nor the development of an exportoriented BPO sector with the potential for greater domestic outsourcing within Kenya itself (that is Kenyan BPO companies conducting work for other Kenyan companies). Despite a trend of increasing subcontracting already taking place (Mazumdar \& Mazaheri, 2002; Bocquier, 2005), policy-makers and businesspeople conceptualised BPO through the early experiences of India ${ }^{2}$ and the current experience of the Philippines, and not through the experiences of Northern countries, where discussions of BPO have been linked to more negative forms of domestic labour market restructuring.

Drawing on in-depth interviews with 49 BPO managers and policy-makers, this paper examines the development of the Kenyan BPO sector in close detail. We describe some of the difficulties that Kenyan BPO managers have faced in trying to access international work such as lack of managerial experience, lack of personal connections and physical distance from markets. In response, Kenyan based companies have increasingly turned towards Kenyan and East African clients. The Kenyan government has now shifted to promoting higher value IT enabled services (ITES) such as software development and to attracting prominent multinational BPO competitors into Kenya. Policy-makers hope these efforts will position Kenya as a regional ICT and software development hub. While observers continue to discuss the sector in relation to its potential for export-oriented work and international opportunities (Dihel, Fernandes, Gicho, Kashangaki, \& Strychacz, 2012; Hope, 2012; Iraki, 2013; Manning, 2013; Wausi, Mgendi, \& Ngwenyi, 2013), ${ }^{3}$ these shifts suggest that we need to rethink how we approach the Kenyan BPO sector. The domestic turn signals both the difficulties of gaining access to digital work overseas due to the power of existing incumbents and to the increasing availability and use of the internet within Kenya. In the conclusion, we discuss what these shifts might mean for the future of the sector and its workers.

The paper draws on the results of a research project carried out by the University of Oxford, the University of Nairobi and the National University of Rwanda over the course of 2012 and 2013 . $^{4}$ 41 managers of Kenyan BPO and ITES companies were interviewed in open-ended extended interviews (1-4 hours in length). ${ }^{5}$ A BPO/ITES company was defined as any company that performs or has the potential to perform business processes for clients. The range of participants included aspiring and small-scale BPO/ITES entrepreneurs (self-employed), more established Kenyan companies in the East African Small and Medium Enterprises segment, international companies with Kenyan offices, Kenyan companies working as representatives of international companies, and Kenyan and Indian BPOs operating in the East African and international market. Additional interviews were conducted with the Kenyan ICT Board, the Permanent Secretary of ICT, an advisor to the National Communications Secretariat, the Head of the Communication Workers Union and representatives from kLab, mLab and $88 \mathrm{mph}$ (three tech hubs and business accelerator programmes in Nairobi). All 49 interviews were transcribed and coded using a qualitative data analysis software tool. 
This analysis was further supplemented by the use of secondary sources like newspaper articles and social media reports, and through on-going communication with research participants. A focus group was held in May 2013, in which research participants were asked to reflect on preliminary findings and to offer their own ideas. With the exception of public statements that have already been made public, the identities of respondents have been anonymised so as to ensure confidentiality. Fieldwork sought to uncover whether or not the arrival of fibre optic internet in 2009 had allowed managers of Kenyan BPO and ITES companies the opportunity to more effectively compete for international BPO contracts and work opportunities. During fieldwork, we discovered that many of the companies included in our sample had refocused towards the domestic market. This paper aims to explain that refocusing and explore its implications.

We first describe the initial hopes for the sector voiced by business people and policy-makers prior to the arrival of fibre optic cables. We then proceed to a discussion of what transpired between 2004 and 2014. Despite substantial investments in infrastructure and marketing, Kenyan BPO firms have struggled to reach into international markets and have increasingly concentrated on local and regional markets.

Sections three to five look at this re-orientation in closer detail. We use the concept of 'sensemaking' to understand how Kenyan actors responded to these difficulties. The concept of organisational 'sense-making' (Weick, 1995) refers to the processes through which individuals attempt to understand uncertain and ambiguous circumstances and make sense of their realities. Sociologists and anthropologists have used the concept to understand how virtual or technologically-mediated communities have built common understandings and practices through geographical proximity and shared cultures (Beunza \& Stark, 2003; Corbridge \& Thrift, 1994; Cramton, 2001; French \& Leyshon, 2004; Kumar, Van Fenema, \& Von Glinow, 2009; Marazzi \& Mecchia, 2007; Spence \& Carter, 2011; Stark, 2009; Steinmueller, 2002). In the case of Kenyan BPO, we show how domestic outsourcing came to be seen as a way of bringing 'global practices' into proximate arenas within which Kenyans could make sense of them. The 'domestic turn' should thus be understood as an opportunity for Kenyan companies to better position themselves in international BPO networks while capitalising on the deepening of internet penetration and ICT-enabled automation taking place in local markets. While BPO has been touted as a job creator and export earner, the Kenyan sector is now gearing up towards changing local business models and work practices.

In the conclusion, we suggest that this re-orientation should involve a more pragmatic discussion within the country. Specifically, we discuss whether increased domestic outsourcing is likely to increase forward and backward linkages between multinational BPO networks and Kenya's own national economy, whether these linkages are likely to increase the potentials of disinvestment and relocation or instead increase the potential for economic upgrading within the Kenyan economy and whether or not the sector is likely to provide stable employment prospects for its workers. We draw on the experiences of India and the Philippines to understand these shifts.

\section{Visions of the Service Sector in Kenya}

In the early 2000s Kenyans began to get interested in BPO. The country needed to create jobs for its growing pool of university graduates, to diminish its dependence on primary commodities and to create export earnings to address its external debt. It was hoped that the BPO sector would help meet all of these objectives by re-orientating the economy away from agriculture and manufacturing and re-positioning Kenya within the global service economy.

On the ground, much small-scale BPO was already taking place. Internet cafés moonlighted as BPO operations afterhours, taking on piecemeal work obtained from online outsourcing platforms like guru. com, odesk.com and elance. ${ }^{6}$ One such operation was E-Business, ${ }^{7}$ a two-person operation founded in 2002 that did online research jobs for foreign clients (Singer, 2006). By 2006 the company had changed its name to Preciss International and had grown its staff to 17, doing a wider range of online tasks. Stories about such companies circulated through the conversations and imaginations of Kenyan 
businesspeople and policy-makers and provided some justification for optimism about a changing relationship between Kenya and the outside world. A number of more established businesspeople began to make substantial investments.

One such person was Nik Nesbitt, a Kenyan businessman working overseas who had planned to return to Kenya to start a business. BPO seemed perfect; it was aligned with the country's wider ICT aspirations, it appealed to government and was understood to be a job creator and export earner. Nesbitt founded Kencall in 2005, setting the stage for other professionally orientated BPOs to enter the market. Technobrain, Horizon, Direct Channel, and Adept (among others) all had large workforces, employing 100-500 workers and initially focused on international work. Of the companies listed above, almost all reported close to 100 per cent international ${ }^{8}$ clients before 2009 . As the sector began to grow, a Kenyan BPO and Contact Centre Society formed in 2007 and membership soon grew above 30 firms. This association was modelled on India's NASSCOM and the Philippines' BPAP, and was intended to bring players together to improve skills, training, government policy and marketing activities.

In 2007 the government named BPO as one of the six pillars of economic growth in its Vision 2030, a national development plan that sought to establish Kenya as a middle-income country by 2030 (Government of Kenya, 2007a, b). Envisioning Kenya to become the top offshoring destination in Africa, it called for the establishment of a 7500 seat BPO park at the Athi-River Export Processing Zone (EPZ), an aggressive marketing campaign, the development of targeted training programmes, the development of a BPO incentive framework and the formulation of BPO and Contact Centre (CC) policy. BPO was estimated to create at least 20,000 direct BPO jobs and contribute 10 billion Kenyan shillings to GDP. The government also established the semi-autonomous Kenya ICT Board to help promote the sector. In 2008, this board launched 'the Kenyan BPO Value Proposition' and embarked on an ambitious marketing tour of BPO conferences and trade shows around the world.

In 2009, the government commissioned the consulting company McKinsey to compile a report on Kenya's niche within the global market for BPO/ITES (Kariuki, 2010). It confirmed that Kenya could become competitive in call centre and customer service work, stressing Kenyans' neutral English accents and the high number of university graduates in the country. ${ }^{9}$ As Kleibert $(2014$, p. 247) has demonstrated in the Philippines, 'research reveals that location choice factors for BPO companies tend to be primarily shaped by the availability of skilled labour force or "talent"”. The Kenyan ICT Board made visits to countries such as India and the Philippines to sharpen Kenya's value proposition vis-àvis other destinations in the world. An interviewee who had also worked as an advisor to Indian and Chinese BPO destinations, surmised Kenya's advantage as such:

The good thing about call centre [work] is the [Kenyan] accents are very, very good and neutral. Number two is there are some amount of saturation levels reaching India and Philippines, and number three is attrition levels in these countries and companies operating in these companies are crazy high ... So I think the customers are ... saying 'I need ... a new source'. (Interview, Nairobi, 22 November 2012)

Kenya sought to position itself as this new source of export-oriented customer service skills. In 2008 Kencall won the Best-Non European Call Centre Award at the Call Centre Focus Conference, the biggest trade show in the industry. This accolade effectively put Kenya on the BPO map. The only thing that held the country back, it seemed, was its expensive and unreliable satellite internet connections.

Before 2009, East Africa was the last region of the world not connected to the global fibre optic grid, and so while Indian and Filipino BPOs were paying \$250 per unit for their monthly bandwidth, a similar connection was costing Kenyan companies as much as \$1,700 (Mark, 2008). ${ }^{10}$ The decision-making process involved in the BPO sector often begins with a discussion of 'seat price': the cost of a workstation per day. With its unusually high internet costs, Kenya was relatively expensive despite its favourable accents and skills (Waema, 2009). As such, the gate to the international economy had yet to open. 
But plans were being made to bring a series of undersea fibre optic cables to the port of Mombasa and thus to theoretically transform East Africa's connectivity. This connectivity was publically linked to the BPO sector, with Kenyan politicians and businessmen repeatedly stressing that the cables would connect East Africa to the global service economy (Graham \& Mann, 2013). The cable projects included: (1) SeaCom, a privately owned cable, dominated by investment from South Africa, ${ }^{11}$ (2) EASSy, a public-private partnership between predominantly South African private investors ${ }^{12}$ and development financial institutions ${ }^{13}$ and (3) TEAMs (The East African Marine System), a Kenyan government led initiative in partnership with Kenyan internet service providers (ISPs) and the UAE based company, Etisalat. While the government and Kenyan BPO operators stressed that the cables would facilitate the growth of an export-oriented BPO sector, and thus strengthen Kenya's links to the outside world, it is likely that internet service providers envisioned the cables deepening links within East Africa and thus facilitating the distribution of new services to Kenyan and other East African consumers. Seacom came online in 2009, followed by TEAMs and then EASSy in 2010. In April 2012, a fourth cable, Lion-2 also came online.

The manager of one of the largest BPOs in Kenya described the arrival of the cables as the linchpin:

We thought it would be a marketing tool and we thought it would make all the difference because ... we had all the raw ingredients from the supply side ... the people, the policies, the willingness to support the industry from the government['s] standpoint, it's a favourable climate with many of our international clients ... So we thought we had a lot of those things and now we've got fibre.

What else is missing? (Interview, Nairobi, 29 November 2012)

Construction began on the cables in 2007 and the Kenyan government decided to use 78 million Kenyan shillings (about \$920,000) from the World Bank Transparency Communication and Infrastructure Programme (TCIP) ${ }^{14}$ to subsidise the cost of bandwidth for BPO companies while the country waited for the cables to arrive. It is illustrative that the government used funding earmarked for e-government to promote BPO, thereby revealing the importance of the industry from the government's perspective. The deputy CEO of the ICT Board, Victor Kyalo described how ' $[t]$ he purpose of offering subsidy to the BPO sector is to make them competitive in the global market' (qtd. in Mark, 2008). While the subsidy was designed to support existing BPOs struggling with costs, it also had the effect of increasing excitement about the sector and therefore encouraging new firms to enter.

The stage had been set for the BPO sector to thrive. Managers had invested large amounts of their own private money into the sector, building facilities in Nairobi and taking on large workforces in anticipation of international contracts. The government had also made substantial investments, financing fibre optic infrastructure, subsidising bandwidth and introducing training programmes. The sector had ultimately been framed as an export-oriented sector - with the development of EPZs, the use of research to identify a national comparative advantage vis-à-vis other foreign destinations and the launching of an aggressive international marketing campaign. It was intended that Kenyan owned companies would drive the expansion of the sector.

At this point, it was not clear that smaller, or less experienced companies might damage the reputation of larger players by weakening the image of Kenya as a whole. Rather, there was a general push towards generating unbridled excitement about the sector within the country. In this way, policymakers and private sector spokespeople utilised technocratic ideas about a 'flat' and 'disintermediated' ${ }^{15}$ global marketplace in order to encourage investment and public support of BPO.

However, despite initial enthusiasm, business strategies had begun to shift, even by the end of 2008 . Companies like Global Connection and Continental had closed their operations, with journalists claiming that even bigger firms were facing closure (Kundu, 2008). After the arrival of the cables, internet prices had not dropped as hoped and firms found themselves struggling to meet costs. The global recession had not helped firms attract international clients (Omondi, 2012).

In both his 2008 and 2012 election campaigns, US President Obama singled out the offshoring of jobs as a key rallying point for his party. In 2008 he repeatedly declared that the United States needed 
to 'stop giving tax breaks to companies that ship jobs overseas' (Thibodeau, 2012). In 2012 he labelled his challenger, Mitt Romney, a 'pioneer in outsourcing' (Dwyer, 2012). While the true impact of the recession on outsourcing is mixed (on the one hand, recession encourages firms to cut costs, but on the other hand, it pressures politicians to erect protectionist policies), ${ }^{16}$ many Kenyan managers cited Obama's speeches as having seriously harmed their businesses. One reason that this discourse might have particularly hurt Kenya, as compared to other destinations like India and the Philippines, was the fact that Kenya needed vocal publicity in order to put itself on the map. By making it difficult for clients to openly endorse a new destination like Kenya, the global recession may have dried up opportunities for new places while maintaining a steady (but less visible) flow to already established countries.

Many Kenyan BPOs went out of business. Others turned to 'impact sourcing, ${ }^{17}$ attempting to position Kenya as a site of corporate social responsibility. The impact sourcing BPO, Digital Divide Data opened an office in Kenya. Similarly the impact sourcing intermediary, Samasource entered Kenya to find partners with whom it could pass on work from its US offices. Some of the most established companies came to depend on Samasource for overseas work, creating minority/disadvantaged segments of their workforce in order to be eligible for these contracts.

Most importantly, by 2013, most Kenyan companies had re-oriented themselves towards the domestic market (that is attracting Kenyan clients). All BPO companies within our sample had taken on local or regional outsourcing work and the majority now had more Kenyan clients than foreign clients (the exceptions were the new impact sourcing companies). Those managers that had had close to 100 per cent international clients in 2009, now estimated that international clients only accounted for 20 per cent to 40 per cent of their clients.

One rural BPO project is particularly indicative of these changes. The Rockerfeller Foundation and Enablis (a foundation that promotes entrepreneurship in low-income countries) had teamed up to launch a rural BPO project in the city of Kisumu. The project was initially designed to encourage a large number of individual 'entrepreneurs' ${ }^{18}$ to start their own small BPO outfits geared towards international work opportunities. Later these 'entrepreneurs' were instead encouraged to join together as worker-partners in a single company when the challenge of gaining work became more apparent and the organisations realised that they could not operate at scale. The two parent organisations then began to focus on getting the company local work, stressing the project's role in increasing efficiency within local government.

This turn towards the domestic economy was reflected in the statements of key government officials in the ICT Board and the Ministry of Information who now declared local outsourcing a way of making the economy more competitive. In September 2013, Ratio Magazine quoted Bitange Ndemo (the former Permanent Secretary in the Kenyan Ministry of Information and Communications) explaining the government's shift:

Mid-stream we changed policy and indeed communicated that we had shifted from marketing Kenya abroad to local outsourcing. ... It was pointless to continue marketing Kenya abroad when we had sufficient work locally. ... Once we became proficient and realised internal efficiencies, then we could now move to the outside world. We still have the opportunity to use this strategy. (qtd. in Ratio Magazine, 2013)

In our interviews with representatives with the Kenya ICT Board, we were likewise told that the government was now focusing on both stimulating local demand for BPO and attracting large international financial, IT and BPO companies into the country in order to jump-start the sector. As we will explain below, this idea was generally supported by private sector actors. It might seem puzzling why Kenyan operators would want multinational competitors to enter the country - but as the next section demonstrates, these managers had come to appreciate the fact that rather than operating in a flat or disintermediated economy, they operated in an extremely personal, socially connected economy. As Graham et al. (2015) demonstrates, ideas of 'disintermediation' have featured prominently in transnational discourses around the promises of changing connectivity for low-income countries. Despite the fact 
that they contradict many actual business practices, these discourses continue to be reproduced internationally and within East Africa, even now that the region has fibre-optic connectivity. Nevertheless, within the sector, Kenyan managers had developed more nuanced understandings. They now saw their international competitors as collaborators in improving the image of Kenya in the eyes of foreign clients. BPO came to be spoken about in a new way. Discourse shifted towards promoting BPO as a way to 'modernise', 'digitise' and 'increase the efficiency of' Kenyan organisations.

The next section discusses this shift in more detail, identifying three stages: (1) early mistakes of judgement, (2) realisation of Kenya's bargaining position within the international marketplace, and (3) pragmatic response. We show how the renewed focus on domestic outsourcing resulted from both pragmatic realisations about the role of powerful interests in international BPO networks and from the increasing penetration of the internet into Kenya itself.

\section{Early Mistakes of Judgement}

While the hype around the arrival of the cables succeeded in generating excitement and investment from domestic investors, some of this hype encouraged inexperienced and small-scale operators to enter the sector. Larger firms like Kencall and Horizon had drawn on Indian, Filipino and American consultants and employees to help structure their operations and train their workforces. Impact sourcing BPOs were likewise supported by international backers that helped them to access foreign expertise. The CEO of the impact sourcing company, Daproim travelled to the headquarters of Digital Divide Data in Cambodia to receive training while workers from impact sourcing Africa, the rural BPO project in Kisumu, travelled to India to receive training from their Indian partner, Ruralshores (Sheth, 2013). Smaller outfits without this international support found themselves in less than profitable circumstances. In particular, less experienced Kenyan managers found it difficult to make sense of the variable costs and values of different forms of work and thereby judge their own capacities to meet deadlines and make profits.

'Joseph', an interviewee who trained BPO managers and employees, used a spreadsheet to explain the complicated matrix he used to determine profitability. He had designed his own formulas and showed the careful calibrations he used to determine different work scenarios, asking questions such as if $x$ number of workers are missing, how many calls does each individual worker have to complete in an hour in order to meet the client's deadline of y number of sales, given a conversion ratio of $z$ (the number of calls converted to sales)? ${ }^{19}$ Such calculations are complicated for an inexperienced Kenyan manager, who has neither experience nor a clear understanding of the relative costs and challenges of tasks before she takes on a new contract. Because smaller Kenyan companies struggled to make sense of the sector, many made mistakes of judgement.

One manager whose company was considering bankruptcy, explained how he and his colleagues had invested in a smaller sized operation of 15-20 people, hoping to get higher-value engineering work. However, they were encouraged by an Indian company to instead take on lower-value customer service work. It is unclear whether this company was helping or exploiting them, given the kind of low-value, outcome-based work ${ }^{20}$ they sourced. It is clear they wanted a Kenyan partner to whom they could pass on work. As the partnership proceeded, the Kenyan managers discovered that they could not make profits within the terms of the contracts. The interviewee described his dilemma as such:

[W] approached a few people from Horizon and Techno Brain and they told us that we have 100 people at daytime and 100 people at night. Here we are trying eight people in daytime and four at night ... We don't have the scale ... the lady who set this up, she went to India ... and she saw thousands. It was like warehouses full of thousands ... I thought: how are you going to compete? If you've got 20 seats and someone's got 2,000 seats, no matter what it is you're doing, he's going to do it much cheaper than you per seat ... We knew how much it would cost, how much would the Voice Over Internet Protocol cost in America, were we going to go through America or 
going to go through India. We did that sort of research. And we knew what we needed to do to make it work. We couldn't reach the threshold. (Interview, Nairobi, 10 December 2012)

Many of the smaller Kenyan BPO operators faced similar problems of scale. In order to compete and get the kinds of clients they needed, they required bigger workforces. But in order to get the bigger workforces, they needed more consistent and profitable streams of work. They therefore found themselves in a catch-22 situation, compounded by their inexperienced management teams and the tendency for young BPO workers to move on to other jobs during slow periods. In turn, prospective clients looked at scalability and long-term capability.

An interviewee who had acted as an advisor to Indian and Chinese BPO destinations described:

If I'm a client outsourcing I'll have first ask how scalable it is. You know, because tomorrow if you as my vendor will not make profits, then I am at risk as a buyer, because that means if you don't make profits, eventually you'll shut down, okay the quality will go down. You'll not be able to pay salaries. (Interview, Nairobi, 14 January 2013)

The small scale of many Kenyan BPOs held them back. They could not access international work because of their small sizes but they could never grow bigger without larger contracts. Their closures damaged the reputation of the country as a whole and damaged the reputation of even the larger companies (Keeler, 2009). For example, one interviewee who had worked in three different Kenyan BPO companies complained:

Some companies started a bit early, that were very influential and they had some very, very big clients. Now those clients left for various reasons, and when you have such kinds of huge clients leaving the country, to be quite honest, since 2008 when one of the biggest clients left Kenya, we have never seen anything bigger until today. (Interview, Nairobi, 28 January 2013)

This problem was magnified by the government's World Bank funded subsidy, which encouraged inexperienced firms to enter the market. In 2009 responding to criticisms about the subsidy, the new CEO of the ICT Board, Paul Kukubo explained in an interview with Kenya's Ratio Magazine:

A lot of the people who came in to ask for the bandwidth subsidy were new businesses ... Their problem wasn't bandwidth costs, but a basic lack of capacity and understanding of the industry itself. Many small and inexperienced firms have cropped up in response to government incentives, which established BPO companies say is dragging down the industry's reputation. (Ratio Magazine, 2009)

Viewed through a national lens, the closure of some firms made the whole sector seem too immature and risky. This problem was made plainly clear in the focus group, when participants suggested that Kenya should adopt an accreditation scheme to certify new BPO players. The proposal was suggested both as a way of giving advice and support to new players and of preventing inexperienced and unprofessional players from damaging the country's image. Rather than Kenyan companies interacting remotely through a 'global' or 'flat' marketplace, each individual owner came to see how they operated within an international context, in which companies were judged in part by their national attachments. The good faith that had been extended in 2008 and 2009, when the Kenyan marketing campaign was in full swing, had faded by 2012 and 2013 and larger Kenyan BPOs found themselves on the back foot. This brings us to the second phase: realisation of Kenya's bargaining position within the international market.

\section{Understanding One's Bargaining Position}

While the BPO sector is global in scope, and many of its processes are standardised, the sector is still characterised by hierarchies of expertise bound up in particular geographical locations and socio-economic 
hierarchies (Dicken, 2003; Malecki \& Moriset, 2008). In such a context, 'sense-making' (Weick, 1995) requires the close collaboration of partners situated in other areas. To better understand how this geography affects Kenyan companies, Author 1 asked focus group participants to draw representations of their companies' value chains. We include a sample of these representations.

Figure 1 depicts the reliance of Kenyan companies on intermediaries in order to access work contracts. This particular participant interpreted this reliance as preventing his company from providing secure employment to workers. Figure 2 demonstrates the importance of having 'presence in client countr[ies]' while Figure 3 shows the high costs of hiring direct employees in Western economies and the distrust that participant had of existing agents who 'are not that beneficial'. Together, these drawings depict the struggles Kenyan managers face in establishing contact and trust with clients across distance.

As others have noted, the difficulties in calculating the intangible values and immaterial labour of BPO work makes negotiating new contracts challenging (Marazzi \& Mecchia, 2007; Spence \& Carter, 2011; Steinmueller, 2002). Hawkins, Mansell, and Steinmueller's (1999) show that while ICT infrastructures may theoretically allow for a disintermediation of work, such disintermediation 'challenges the business of many existing companies' (p. 383), who may not so easily hand over access to existing chains of value. For the client, there are costs associated with new suppliers and so clients 'place value on cultivating stable communities' (p. 387). While these stable communities serve to stabilise the flow of commodified work across distance and allow for participants to make sense of their environments, they are made up of incumbent firms and consultants motivated by their own interests. The globalisation of such work therefore requires social negotiation and alignment of corporate strategies across firms.

Impact (or social enterprise) intermediaries like Samasource have offices in the United States and trusted agents who assure clients face-to-face that projects will be completed in a timely and professional manner. Larger Indian and US BPO companies also have such presence, maintaining offices in several different regions and shifting work between workforces within their networks. These companies have built brand names, reserves of customer loyalty and tacit knowledge of the processes and the wider market. Once their representatives have secured a contract from a client, they typically break that contract into smaller packages to divide among smaller units and associates. While smaller companies receive lower margins from subcontracting in this way, they value having a steady flow of work, as it allows them to maintain their workforces.

While managers of impact sourcing companies may be motivated by altruistic wishes to help (and by social enterprise business models that generate value from the framing of their intermediation as altruistic ${ }^{21}$ ), most larger companies are motivated by straightforward profit calculations. They may pass on work packages that are either unprofitable or that other workforces might be able to complete

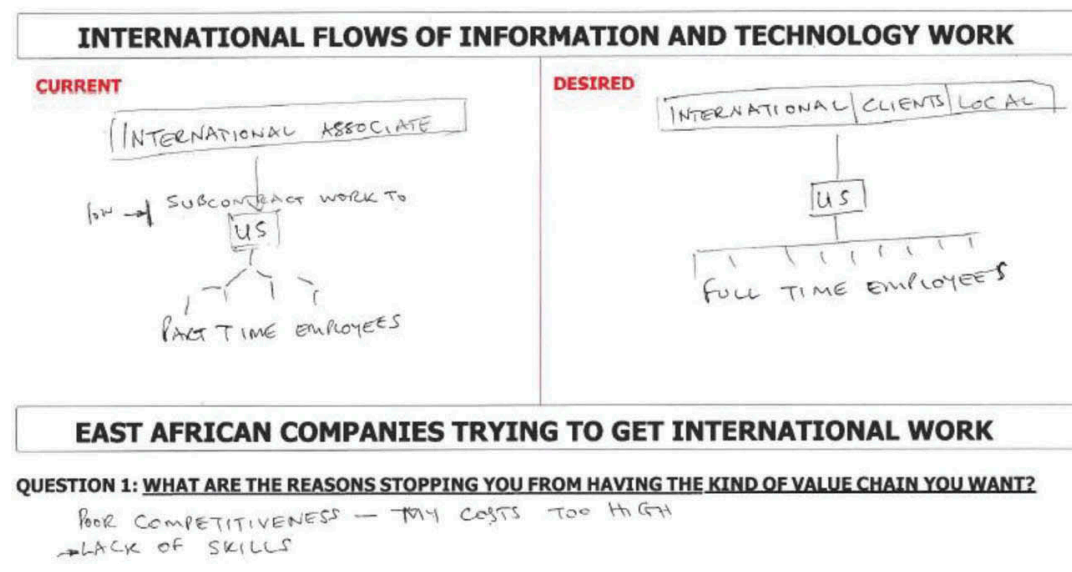

Figure 1. Intermediation within International BPO flows. 


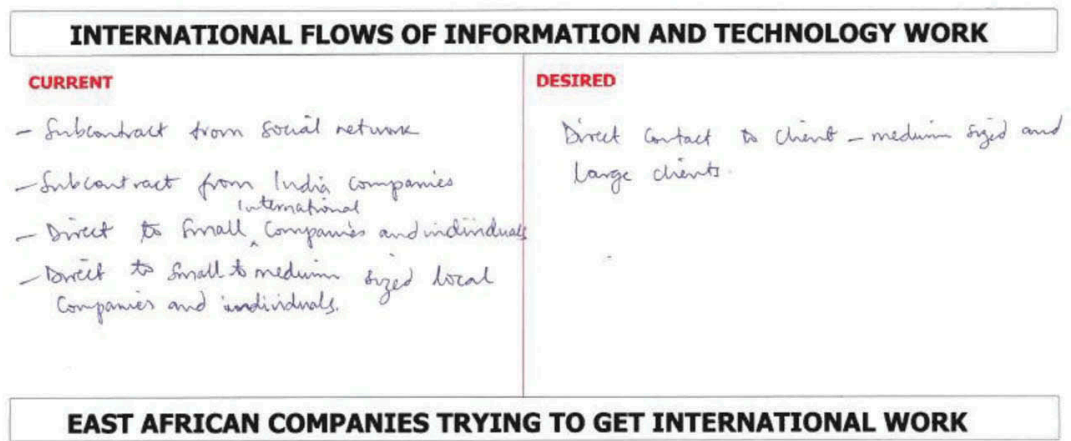

QUESTION 1: WHAT ARE THE REASONS STOPPING YOU FROM HAVING THE KIND OF VALUE CHAIN YOU WANT?

$\rightarrow$ Trust from the end client

$\rightarrow$ Access to the " "Presence in chine cornting

Figure 2. Importance of 'presence'.

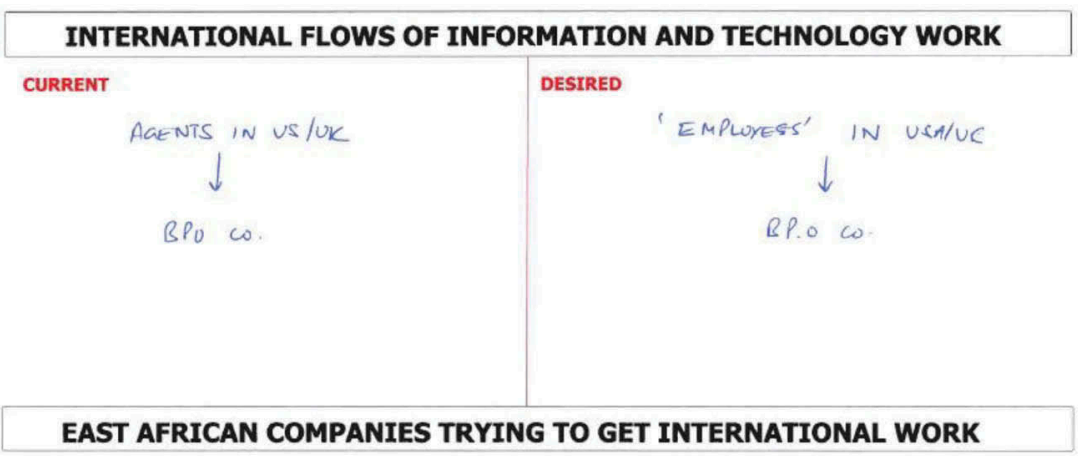

QUESTION 1: WHAT ARE THE REASONS STOPPING YOU FROM HAVING THE KIND OF VALUE CHAIN YOU WANT?

- COSTS ARE PROHBITIVE TO HIRE EMPLOTEES IN WESTERN ELONCMIES

- ACENTS ARE nUT THAT BENEFICIAL - ES

Figure 3. Importance of agents in client economies.

more effectively. Some Kenyan managers believed that foreign associates passed on work that Kenyan workers were better positioned to complete (due to their more neutral English accents), but others suspected their collaborators were only passing on low-value work, while retaining higher-value contracts. Lastly, and perhaps most importantly, established incumbents may be interested in a new destination like Kenya, not just as a source of new workforces, but as potential markets for their own service centres. Multinational companies may therefore wish to develop relationships with local Kenyan companies as a way of gaining access to new opportunities within the country. This last point is especially relevant for Kenya, as Nairobi and Mombasa are transportation and financial hubs for the rest of East Africa.

Like any new firm or country wishing to join this global trade, Kenyan policy-makers and businesspeople must therefore contend with these incumbent networks and determine the strength of their own bargaining positions. Managers are conscious of the fact that they are not the only country in the world trying to engage. As a manager of one of the largest Kenyan BPO firm described:

Something like 70 countries have written 'BPO' on their own Vision 2030, 40, 50, so they're all competing for it, and so they would all love to have the Indians come into their country, all the 
Americans and Europeans, which means that those companies are in a buyers' market. So if I'm going to go into Togo or Kenya, Uganda or Botswana: 'What are you going to pay me as a business?' and under the table, 'But what are you going to pay me to come in here?' 'And if you're going to pay me want I want' - oftentimes it's about $£ 10,000$ per person - 'then I will comply with your rules, but if you're going to tell me, 'Come in and build your own place and all that stuff, and then pay more for your staff' I'll go to Uganda, I'll go to Botswana.' So there's that competition. (Interview, Nairobi, 22 November 2012)

This competition to attract foreign investment makes the BPO sector particularly vulnerable to exploitation by intermediaries and incumbent firms. ${ }^{22}$ Mytelka has thus referred to it as a 'locational tournament' (1999). Kenyan actors are particularly vulnerable due to the late stage in which they are trying to enter.

China and India's early development of BPO in the 1980s and 1990s took place in the context of the dot-com bubble and a drop in international internet costs that made the globalisation of services first possible. Thus their BPO industries benefitted from a first-mover advantage (Athreye, 2003; Carmel, 2003; Krishna, Ojha, \& Barrett, 2000). Jana Kleibert has shown how the later entrance of the Philippines meant that it developed a very different model. While local businesses drove the growth of India's BPO sector and such firms have since grown into multinationals in their own right, the Filipino sector is dominated by large multinationals that have almost entirely bought out local companies. Foreign equity in the Philippines' service sector is 93.3 per cent (Yi, 2012, p. 137). While Indian firms were greatly strengthened by strong diaspora links with the United States due to the migration of Indian professionals seeking educational opportunities, the Philippines did not have these same networks. The country lacked relationships with US businesses and had not developed specialised skills like software development. Further, because the Philippines entered the sector when voice-based work was becoming more affordable, it has become dominant in call centre work and has now displaced India as the biggest customer service destination in the world (Kleibert, in press).

Kenya's experience thereby reflects the moment in which the country entered the international market. It was difficult for the country to compete with destinations like India and the Philippines in areas such as voice-based service work, due to the tendency of clients and multinational BPOs to cluster in areas with a proven track record (Kleibert, 2014, in press; Milberg \& Winkler, 2013). However, in other areas like mobile phone app development and social media based work, the field might be more nascent and open. Kenya is also privileged in terms of its strategic position within East Africa.

The Kenyan market therefore offers certain opportunities to international service providers; the question is whether it can exploit this position and retain work opportunities within the country. In the next section, we argue that domestic outsourcing has come to be understood as a way for Kenyan managers to both make sense of incumbent networks and as a way to capitalise on the growing penetration of internet into Kenya's (and other East African countries') organisations.

\section{Pragmatic Response}

After the arrival of the submarine fibre-optic cables, many Kenyan BPO companies had come to appreciate the difficulties of accessing foreign work and dealing with intermediaries. But, in the background, other changes were taking place. The arrival of the cables not only made international connections more affordable, but also made connections within the country more affordable and common.

The deeper penetration of internet and mobile connectivity changed the broader environment for ICT-led economic development. The government thus started to shift its funding and policy-making attention to software developers and other high-value producers, most visibly in the celebration of cases like Safaricom's mobile money platform, M-Pesa and the disaster response crowd-sourcing tool, Ushahidi. The government also began to realise the potential of ICT automation for centralising 
control over government budgets and reducing corruption and waste. In the summer of 2013, the Kenya Revenue Authority announced that it would become mandatory for all medium and large taxpayers to file and pay taxes electronically (Mutai, 2013). Similarly, it was announced that it would start digitally tracking M-Pesa and bank transfers to identify non-tax paying traders in the informal economy (Omondi \& Juma, 2013). ${ }^{23}$

This drive towards efficiency and automation is further taking place in an environment of growing subcontracting within the labour market. As a 2005 study by Philippe Bocquier has found, 88 per cent of Kenyan informal employees were actually employed on flexible contracts by formal firms (Bocquier, 2005). While Kenya is particularly marked in this growing flexibility/informalisation of the labour force, this state of affairs is becoming so conspicuous throughout Africa that the ILO has reclassified the 'informal sector' as the 'informal economy' to account for informal workers working for formal sector firms, facilitated by outsourcing or labour contracting arrangements (International Labor Organizations [ILO], 2009). The introduction of software and ICT automation has the potential to extend sub-contracting employment relations to more middle class or professional workers, with the attendant risk of informalisation in future. In this environment, BPO has come to be conceived as part of a broader transformation of the national economy, as developers in ICT hubs are being encouraged to digitise information systems and 'digitally enable' value chains within Kenya's local economies through software and mobile applications.

By 2012, the Kenya ICT Board had changed its mandate from promoting BPO to promoting ITES. Similarly, a planned 7500-seat BPO park was renamed as the technopolis of Konza City. It was noticeable that BPO was only mentioned in passing at the Konza City opening ceremony. Instead there was much talk about attracting big multinational companies to the industrial park. ${ }^{24}$

Within this broader transformation, managers of Kenyan BPO companies found their place. Domestic outsourcing came to be understood as a way for Kenyan managers to make sense of the industry and manage the wider restructuring of the local economy to their benefit. It would allow Kenyan managers to retain their workers, build up competencies and expand their portfolio of clients. It would also allow foreign actors to evaluate Kenyan capacities. Many foreign clients began to ask, 'What have you done locally?' as a way to gauge competence.

An interviewee who had worked for two BPO companies before becoming an impact sourcing advisor commented:

[W]e would like to get more work from the government, we want to get more local content into the hands of this people that can be done and there's a lot of work e-governance and just generally hospitals ... So we have had an immense targeting banks and hospitals and the government just to talk about how outsourcing can get into that. ... The Kenyatta national hospital for example, I'm told has data that dates back to 40 years ago and they did, they started digitising just a small section of it, I think about 40 million records or some big number like that ... So when you look at all the faculties in the hospital it means that we haven't even scratched the surface. So there's a lot to be done. (Interview, Nairobi, 29 January 2013)

The manager whose company had struggled to get international clients commented:

Banks, insurance companies. Manufacturers, for example, we tried to talk to manufacturers about outsourcing their distribution and stocking and knowing which depots need what and all that sort of thing, but they want to hold it in, I think it's trade secrets they're worried about. Alternatively, the Kenya government could promote outsourcing in the domestic market in particular with the government and the companies in which it has shares. So Safaricom has 1500 people and they want to hire another 500, Kenya government owns a large part of Safaricom, if they were to say, 'Safaricom, you need to reserve 300, 400 seats for Kenyan outsourcing business', that would do a world of good to any one of the one, two or three guys that participated in that, it could change their fortunes overnight, they could afford to do A, B, C, D. (Interview, Nairobi, 10 December 2012) 
The domestic turn was not just a matter of turning to domestic clients in the absence of international clients, but rather it was also an attempt to make the most out of the country's deepening internet penetration and to use the domestic BPO market as a way to build local understandings of the sector and improve the country's global recognition. For this reason, almost all our interviewees claimed that they wanted Indian and other multinational BPO competitors to enter the country. A manager of a large, well established Kenyan BPO asserted that:

the government could help these companies to get business through a secondary effect such as promoting Indians and others to come to Kenya, therefore it looks like Kenya's attractive, therefore people who don't want those guys may now pick the Kenyans and the Kenyans get more business. (Interview, Nairobi, 29 November 2012)

Another interviewee reinforced this belief, asserting that Indian companies would bring work to Kenya from existing clients:

The good thing about Spancos and Tech Mahindras [Indian BPO companies] of the world is they have the financial muscle, but more than that they have the global leverage. So they have, the only service various customers from India, from China ... For example ... when they ... say 'now we have a centre in Kenya as well' so ... a big, large company, ... fortune 100, fortune 500, might come and say, 'Fine I'd like to try it out in Kenya'. (Interview, Nairobi, 22 November 2012)

The entrance of such companies was seen by BPO managers to provide a 'demonstration effect" 25 and thus normalise Kenya's reputation as a mainstream destination in the eyes of global clients. One manager even suggested that the government should lure one large multinational BPO company into the country through a lucrative opportunity in a parastatal or other large Kenyan company that would make it affordable for it to enter. Once established, the manager hoped that the multinational company would then expand its operations, attracting contracts with prominent international clients and providing workers and managers with experience and understanding of the systems and processes required.

It was no longer a case of individual Kenyan companies seeking to engage remotely (and some might say, without being identified as Kenyan), but rather making the Kenyan brand something unique. If they could transform the image of the Kenyan economy into an 'ICT hub' through the celebration of software development and automation, then they could create a regional cluster that multinational competitors would want to join. The technocratic discourse that pervaded the speeches of politicians and the media reports on BPO prior to 2009 was thus replaced by a pragmatic realism that even in the digitally-enabled information economy, information flows through people and places. The fibre optic cables have thereby enabled a two-way globalisation of services: the cables have made it possible for Kenyan BPO companies to physically access international work opportunities, but they have also facilitated the entrance of international businesses and work practices, deepening existing tendencies of digitisation and casualisation of labour.

\section{Conclusions}

The nature and value of work in the service economy is particularly hard to quantify and communicate to others (Spence \& Carter, 2011). As Marazzi and Mecchia (2007) have argued, the production and expropriation of such value from information requires both technological ICT infrastructure and 'socio-cultural machineries' and 'cognitive capital'. The tendency with ICT investments has been to see them as technocratic solutions and as 'win win' scenarios for all participants, but as countries like Kenya gear up to restructure the local economy and engage in flows of international service work, they must bear in mind that powerful incumbent networks exist with their own sets of interests. One does 
not simply 'tap in' or 'log on' to global opportunities. While high internet and labour costs still hamper Kenya's international competitiveness, perhaps the most formidable barrier has been social distance from clients and knowledge flows. Quite simply, globalisation of services has been structured by power relations (Cooper, 2001). As Massini and Miozzo (2012, p. 19) describes, the relative power of American and European interests vis-à-vis other destinations like India and the Philippines means that higher value activities still remain in advanced economies.

After 10 years of experience, Kenyan managers and owners have gained a keen awareness of how the digital economy actually works: economic opportunities flow not only through fibre optic wires, but through people with their own private interests at heart. Seen in this light, joining the digital economy ultimately means negotiating opportunity with these interested parties and making shrewd decisions about how best to gain strategically from wider restructuring patterns happening within companies both across the globe and within Kenya itself.

The targeting of local clients by BPO companies and the encouragement by government officials to spur ICT innovation (and thus increasing data flows within Kenyan economies and organisations) contains both opportunities and vulnerabilities, unevenly spread between groups. On the positive side, the synergy between the BPO sector and local software developers could allow Kenya to develop a longer-term potential for higher-value BPO. Jyoti Saraswati (2012) has demonstrated the important role played by India's software industry in building relationships with American companies and thus allowing Indian BPO companies to transition from low-value customer service work into higher value services (see also Athreye, 2004). Kenya's current strategy to position the country as an African ICT hub might provide opportunities for Kenyan actors to mimic this experience.

The domestic turn can also serve to more deeply embed the BPO sector into the local economy, potentially creating frontward and backward linkages with Kenyan firms in other sectors. This tendency might cushion the country from external shocks and thus prevent it from developing into a branch-plant economy dependent on fleet-footed multinational companies (Phelps, 2008; MacKinnon, 2012; Kleibert, 2015). These frontward and backward linkages decrease the likelihood that foreign investment will move elsewhere when costs change. If Kenyan clients are involved in negotiations and decision-making between multinationals and Kenyan government officials, then it is possible that multinationals may keep managerial and client-relationship activities within Kenya. These considerations further demonstrate the need for nuanced understandings of BPO and ITES.

On the negative side, however, the Kenyan government's desire to attract multinationals may mean that Kenya follows the trajectory of the Philippines, where domestically owned BPO companies have mostly disappeared. Foreign buy-outs could potentially remove decision-making within such organisations overseas, leading to weaker skill upgrading and social mobility within firms. This loss of control could also mean that foreign companies and governments will have better access to Kenyan government and corporate data flows, which may pose security and ethical implications in future. ${ }^{26}$

Lastly, we must consider the impact on labour relations within Kenya. One might charge that domestic outsourcing is merely a more elaborate way of saying that ICTs are contributing to an informalisation of employment for middle class workers. The re-casting of outsourcing arrangements in the more positive language of BPO shields us from scrutinising the way that deeper ICT penetration might be changing relative bargaining positions. For example, Hope (2012) cites the growing share of services in Kenya's GDP as a sign that the BPO sector is growing successfully, without mentioning that BPO currently accounts for a small share of the much larger and generally informal service sector. Trade in services is dominated by tourism and travel, not BPO (Dihel et al., 2012). Yet commentators still highlight BPO as central when talking about Kenya's service sector. Similarly, while interviewees described how Kenya should mimic the experience of South Africa in building up its service sector, there is evidence to suggest that the structural transformation of the South African economy has been overestimated and that the impressive growth of services might simply be a statistical illusion driven by the outsourcing of 'relatively low-skilled, low-technology activities with limited scope for cumulative productivity increases and negligible potential for generating foreign exchange' (Tregenna, 2010, p. 21).

As many of the managers who established Kenyan BPO operations framed their investments as ways to tackle joblessness, it is important to ask what BPO will do to the Kenyan economy in the 
future: Will it create jobs? And will it create the kinds of jobs that both young Kenyans and economic planners want? Benson Okwaro, the head of the Kenyan Communication Workers Union (CWU) expressed concern that the outsourcing of work within the communication and technology sector could follow the experience of outsourcing within the security services, where private contractors have made it difficult for traditional unions to organise and collectively bargain. The specific characteristics of the BPO sector pose particular challenges. The informality of the sector and its high turnover rates make it hard for unions to maintain contact with members and forge common identities and interests over the long-term (Noronha \& D'Cruz, 2006). These challenges are compounded by the commodification and re-distribution of service work across organisational boundaries, which further impede traditional union strategies. Such concerns have been raised by Alex Free (2015) in a recent paper on worker experiences within the Kenyan call centre sector, who found that when companies experienced financial difficulty, workers struggled to receive their wages and found it difficult to seek redress. They felt that their positions were insecure and that they could 'be readily dismissed as easily replaced cheap labour, especially ... [as] those working in BPO are subject not only to their own company's authority, but also that of clients' $(2015$, p. 60). Finally, there is a danger that domestic outsourcing could lead to a leaking of work to other countries and thus a reduction of jobs, something that some interviewees suggest is already happening.

In sum, this paper has examined Kenya's experience of BPO from 2004 to 2014. We have outlined some of the central barriers that Kenyan BPO managers have faced in trying to access international service work, showing how lack of managerial experience, lack of personal connections and physical distance from markets have all made it difficult for Kenya to emerge as an international BPO destination. In response, Kenyan based companies have increasingly turned towards Kenyan clients, with the Kenyan government now focused both on promoting higher value ITES activities such as software development and on attracting prominent multinational BPO competitors into Kenya. What Kenya now needs is both a more tailored policy to better tackle the changed geographic focus of the sector, and more research into understanding the long-term social and institutional changes that are likely to result. Will changing digital infrastructures allow Kenyan producers and workers to upgrade their skills and assets, and thus increase the country's national competitiveness, or will the closer integration of Kenyan economic activities into international service companies make the country more vulnerable to global shifts? It is too early to predict the full impacts at this early stage but we end by suggesting a more prudent reckoning of both the potentials and vulnerabilities of the changes afoot within Kenya.

\section{Acknowledgements}

The authors would like to thank their collaborators, Timothy Waema and Charles Katua for support and helpful input during fieldwork in Kenya. In addition the authors wish to extends thanks to Kate Meagher, Linnet Taylor, Marie Berry, Jana Kleibert, Henrike Florusbosch and Nicolas Friederici for comments on earlier drafts and to the other participants of the panel, Moving Jobs, Moving Workers at the European Conference on African Studies, where the paper was first presented. Lastly, we wish to thank the anonymous reviewers who gave excellent suggestions on how to improve the paper. The research project at the core of this report is based on an initial pilot research project funded by the British Academy in 2010. The larger project was funded by a multi-year ESRC-DFID grant (RES-16725-0701 | ES/I033777/1). For a more detailed description of methodology employed in the project and for a fuller presentation of the data used, please visit: http://www.esrc.ac.uk/my-esrc/grants/RES-167$25-0701 / \mathrm{read}$

\section{Disclosure statement}

No potential conflict of interest was reported by the authors. 


\section{Notes}

1. In this paper we employ the word 'global' to refer to not just non-local processes and practices, but also processes/practices that are genuinely trans-national and trans-continental in their scope (see also Massey, 2005 for the fuller discussion of the term).

2. Later assessments of the Indian BPO sector reveal that it too is moving towards increased outsourcing within the national economy as well (Jana Kleibert, personal communication).

3. It should be noted that many analyses of the Kenyan BPO sector rely on secondary materials (Bryce, Hartley, Kassam, Saloojee, \& Williams, 2011; Iraki, 2013; Wausi et al., 2013).

4. The project looked at the impact of fibre optic internet connectivity on three sectors of Kenya and Rwanda's economies: tea, tourism and BPO. This paper focuses on the Kenyan BPO/ITES sector.

5. Author 1, Author 2 and Professor Timothy Waema carried out the interviews with BPO managers and Kenyan policymakers $(49,10$, and 2 respectively).

6. These informal operations were described by several interviewees. Some informal work is still taking place. While these platforms are designed to allow individual users to bid for work, in Kenya, some companies ask employees to use these platforms to source work for the whole workforce, using individual profiles in order to do so.

7. It is unclear whether the firm is still in operation.

8. In order to explicitly address the non-local geographic reach of firms, this article uses the term 'international' to refer to all work and clients outside of Sub-Saharan Africa. Although other East African and South African work is undoubtedly international, managers themselves distinguish between international work outside of Africa and regional work within Africa.

9. This segment was also envisioned as complementing other sectors of the economy, like tourism, where customer service and natural accents are also valued.

10. It is worth noting that submarine fibre-optic cables are used for all sorts of digitally mediated connectivity. However, this paper focuses exclusively on internet connectivity.

11. Seacom was formed by the coming together of Industrial Promotion Services (a branch of the Agha Khan foundation in Egypt which owns a $26.25 \%$ stake), VenFin Limited (now merged with Remgro Ltd. - both also South African - which owns 25\%) Convergence Partners (also South African and owning a 12.5\% stake) and Shanduka (also South African and also holding $12.5 \%$ ). The remaining 23.75 per cent was held by Herakles Telecom LLC (an American company).

12. Telkom/Vodacom, MTN and Neotel.

13. These include the World Bank/International Finance Corporation (IFC), European Investment Bank (EIB), African Development Bank (AfDB), Agence Française de Développement (AFD), and KfW (Kreditanstalt für Wiederaufbau).

14. This was a World Bank programme designed to support e-government and ICT outreach projects.

15. For a discussion of the notion that ICTs and internet connectivity 'disintermediate' financial and service value chains, please see French and Leyshon (2004).

16. See James and Vira (2012) for a description of the impact of the financial crisis on Indian outsourcing.

17. Impact sourcing promises clients to provide their work to members of marginal communities.

18. The quotation marks denote the neoliberal framing of the project. Participants were initially framed as being self-sufficient 'entrepreneurs' in line with Enablis general policy. For a broader discussion of the influence of neoliberal ideologies on African economic development, see Harrison (2010).

19. Question paraphrased from interview discussion (Author 1 fieldnotes).

20. Outcome based work is work whose profits are based on favourable outcomes. For example, a company will only be paid for calls that result in a successful sale, as opposed to the total number of calls made. Such work is generally considered to be challenging and unprofitable, especially for inexperienced companies.

21. For a broader discussion of this conversion process within ethical capitalism, see Catherine Dolan's work in this special issue and in Dolan and Roll (2013, p. 129).

22. In focus groups, participants felt that exploitation primarily occurs when there are disparities of knowledge and awareness.

23. It is unclear what legal and ethical protection governs this activity but according to Safaricom's own terms of service, customers give the company the right 'to disclose any Transaction data or information pertaining to your M-PESA Account to any law enforcement, investigative or regulatory authority including without limitation the Kenya Police, Central Bank of Kenya, Kenya Anti-Corruption Commission, Kenya Revenue Authority or any competent Anti-Money Laundering authority for the purposes of any genuine enquiry and investigation ...' This is clearly a controversial activity, and given the contentious nature of debate surrounding Kenya's new data protection law, we are likely to see growing public scrutiny of such behaviour in future. For an indication of the response to such activities from the Kenyan (media-savvy) public, see the blogpost: http://www.thinkersroom.com/blog/2013/07/kra-safaricom-you/

24. Author 1 fieldnotes.

25. For a discussion of the 'demonstration effect' in the Indian BPO sector, please see: Athreye (2003).

26. For a discussion of the privacy and ethical issues of 'big data' in relation to Africa, please see Taylor and Schroeder (2015) and Linnet Taylor's more recent blog entries. 


\section{References}

Athreye, S. (2003). Multinationals and the evolution of the Indian software industry. East-West Centre Working Papers Series, 51. Retrieved from http://scholarspace.manoa.hawaii.edu/bitstream/handle/10125/3664/ECONwp051.pdf?sequence=1

Athreye, S. (2004). Role of transnational corporations in the evolution of a high-tech industry: The case of India's software industry" - a comment. World Development, 32, 555-560. doi:10.1016/j.worlddev.2003.08.011

Batt, R., \& Moynihan, L. (2002). The viability of alternative call centre production models. Human Resource Management Journal, 12(4), 14-34. doi:10.1111/hrmj.2002.12.issue-4

Beunza, D., \& Stark, D. (2003). The organization of responsiveness: Innovation and recovery in the trading rooms of lower Manhattan. Socio-Economic Review, 1(2), 135-164. doi:10.1093/soceco/1.2.135

Bocquier, P. (2005). Informal sector versus informal contracts in Nairobi, Kenya. Document De Travail, DT/2005-10.

Bryce, J., Hartley, S., Kassam, Z., Saloojee, N., \& Williams, B. 2011. Kenya's off-shoring advantage: An emerging BPO cluster in East Africa (Unpublished Microeconomics of Competitiveness Paper). Harvard Business School

Bryson, J. (2007). The second global shift: The offshoring or global sourcing of corporate services and the rise of distanciated emotional labour. Geografiska Annaler, Series B: Human Geography, 89, 31-43. doi:10.1111/geob.2007.89.issue-s1

Carmel, E. (2003). Taxonomy of new software exporting nations. Electronic Journal of Information Systems in Developing Countries, 13(2), 1-6.

Cooper, F. (2001). What is the concept of globalization good for? An African historian's perspective. African Affairs, 100(399), 189-213. doi:10.1093/afraf/100.399.189

Corbridge, S., \& Thrift, N. (1994). Money, power and space. London: Blackwell.

Cramton, C. D. (2001). The mutual knowledge problem and its consequences for dispersed collaboration. Organization Science, 12(3), 346-371. doi:10.1287/orsc.12.3.346.10098

Davis, G. F. (2009). Managed by the markets: How finance reshaped America. Oxford: Oxford University Press.

Dicken, P. (2003). Global shift. London: Sage.

Dihel, N., Fernandes, A. M., Gicho, R., Kashangaki, J., \& Strychacz, N. (2012). Becoming a global exporter of business services? The case of Kenya. In A. G. Goswami, A. Mattoo, \& S. Saez (Eds.), Exporting services: A Developing country perspective (pp. 237-267). Washington, DC: World Bank. Retrieved from https://openknowledge.worldbank.org/bitstream/ handle/10986/2379/658370EPI188160Box365736B0Exporting.pdf?sequence=1

Dolan, C., \& Roll, K. (2013). ASR forum: Engaging with African informal economies. African Studies Review, $56(3), 123-146$. doi:10.1017/asr.2013.82

Dossani, R., \& Kenney, M. (2007). The next wave of globalization: Relocating service provision to India. World Development, 35, 772-791. doi:10.1016/j.worlddev.2006.09.014

Dwyer, D. (2012, June 25). Obama hammers Romney on outsourcing vs. 'offshoring' explainer. ABC News. Retrieved from http://abcnews.go.com/blogs/politics/2012/06/obama-hammers-romney-on-outsourcing-vs-offshoring-explainer/

Fernandez-Stark, K., Bamber, P., \& Gereffi, G. (2011). The offshore services global value chain. Duke Centre of Globalization, Governance and Competitiveness. Retrieved from http://www.cggc.duke.edu/pdfs/2011-11-11_CGGC_Offshore-ServicesGlobal-Value-Chain.pdf

Free, A. (2015). 'Development', profiles and prospects: Labour in Kenya's outsourced call centres. Critical African Studies, 7(1), 47-65. doi:10.1080/21681392.2014.901877

French, S., \& Leyshon, A. (2004). The new, new financial system? Towards a conceptualization of financial reintermediation. Review of International Political Economy, 11(2), 263-288. doi:10.1080/09692290420001672804

Friedman, T. L. (2006). The world is flat: The globalized world in the twenty-first century. London: Penguin.

Graham, M., Andersen, C., \& Mann, L. (2015). Geographical imagination and technological connectivity in East Africa. Transactions of the Institute of British Geographers. doi:10.1111/tran.12076

Graham, M., \& Mann, L. (2013). Imagining a silicon valley: Technological and conceptual connectivity in Kenya's BPO and software development sectors. The Electronic Journal of Information Systems in Developing Countries, 56(2).

Harrison, G. (2010). Neoliberal Africa: The impact of global social engineering. London: Zed Books.

Hawkins, R., Mansell, R., \& Steinmueller, W. E. (1999). Towards digital intermediation in the information society. Journal of Economic Issues, 33(2), 383-391.

Held, D. (1999). Global transformations: Politics, economics and culture. Stanford, CA: Stanford University Press.

Hope, K. R. (2012). The political economy of development in Kenya. London: Bloomsbury.

International Labor Organizations. (2009). The informal economy in Africa: Promoting transition to formality: Challenges and strategies. ILO Report Retrieved July 30, 2013, from http://www.ilo.org/wcmsp5/groups/public/@ed_emp/@emp_policy/ documents/publication/wcms_127814.pdf

Iraki, X. N. (2013). Outsourcing and vision 2030: An analysis into Kenya's new economic frontier. African Journal of Business Management, 7, 1218-1223.

James, A., \& Vira, B. (2012). Labour geographies of India's new service economy. Journal of Economic Geography, 12(4), 841-875.

Kariuki, E. (2010). Progress report implementation of the Mckinsey report BPO/ITES study recommendations. Kenya ICT Board. Retrieved from http://www.horizoncontactcenters.com/ke/userfiles/Mckinsey_Report.pdf

Keeler, R. (2009, June 9). Outsourcing to East Africa: Growth industry or misguided ambition? Ratio Magazine. Retrieved from http://www.ratio-magazine.com/20090609681/EAC-Regional/Outsourcing-to-East-Africa-Growth-Industry-or-MisguidedAmbition.html 
Kleibert, J. (2014). Strategic coupling in 'next wave cities': Local institutional actors and the offshore service sector in the Philippines. Singapore Journal of Tropical Geography, 35, 245-260. doi:10.1111/sjtg.2014.35.issue-2

Kleibert, J. M. (2015). Global production networks, offshore services and the branch-plant syndrome. Regional Studies, Advance online publication. doi:10.1080/00343404.2015.1034671

Kleibert, JM. (in press). Services-led economic development: domparing the emergence of the offshore service sector in India and the Philippines. In N. Beerepoot, R. Kloosterman, \& B. Lambregts (Eds.), The local impact of globalization in South and Southeast Asia: Offshore business processes in services industries. London: Routledge.

Krishna, S., Ojha, A.K. and Barrett, M. (2000). Competitive advantage in the software industry: An analysis of the Indian experience. In C. Avgerous \& G. Walsham (Eds.), Information technology in context (pp. 182-197). Ashgate: Aldershot.

Kumar, K., Van Fenema, P., \& Von Glinow, M. (2009). Offshoring and the global distribution of work: Implications for task interdependence theory and practice. Journal of International Business Studies, 40(4), 642-667. doi:10.1057/jibs.2008.77

Kundu, S. (2008, June 27). Kenyan BPO dream collides with reality. IT Examiner. Retrieved from http://www.itexaminer.com/ kenyan-bpo-dream-collides-with-reality.aspx

Levy, D. (2005). Offshoring in the new global political economy. Journal of Management Studies, 42, 685-693. doi:10.1111/ joms.2005.42.issue-3

MacKinnon, D. (2012). Beyond strategic coupling: Reassessing the firm-region nexus in global production networks. Journal of Economic Geography, 12, 227-245. doi:10.1093/jeg/lbr009

Malecki, E., \& Moriset, B. (2008). The digital economy. Oxford: Routledge.

Manning, S. (2013). Tech support en Francais S'il Vous Plait!? The challenges of becoming a new global outsourcing hub (Organizations and Social Change Research Group Report). University Massachusetts. Retrieved from http://ssrn.com/ abstract $=2258722$

Marazzi, C., \& Mecchia, G. (2007). Rules for the incommensurable. SubStance, 36(1), 11-36. (G. Macchia, Trans.). doi:10.1353/sub.2007.0014

Mark, O. (2008, February 11). World Bank frees funds to support call centres. Balancing Act. Retrieved from http://www. balancingact-africa.com/news/en/issue-no-392/telecoms/world-bank-frees-fun/en

Massey, D. (2005). For Space. London: Sage.

Massini, S., \& Miozzo, M. (2012). Outsourcing and offshoring of business services: Challenges to theory, management and geography of innovation. Regional Studies, 46, 1219-1242. doi:10.1080/00343404.2010.509128

Mazumdar, D., \& Mazaheri, A. (2002). Wages and employment in Africa. Hampshire: Ashgate.

Milberg, W., \& Winkler, D. (2013). Outsourcing economics. Global value chains in capitalist development. Cambridge: Cambridge University Press.

Mutai, E. (2013, July 14). KRA set to make online filing of taxes mandatory. Business Daily. Retrieved from http://www. businessdailyafrica.com/KRA-set-to-make-online-filing-of-taxes-mandatory/-/539546/1914998/-/6bamu0/-/index.html

Mytelka, L. (1999). Locational tournaments for FDI: Inward investment into Europe in a global world. In N. Hood \& S. Young (Eds.), The globalization of multinational enterprise activity and economic development (pp. 278-302). London: Palgrave Macmillan.

Noronha, E. \& D’Cruz, P. (2006). Organizing call centre agents: Emerging issues. Economic and Political Weekly, 41(21), 21152121.

Omondi, G. (2012, February 5). Kenya: BPO firms suffer from worsening job losses in the west. Business Daily Retrieved from http://allafrica.com/stories/201202160548.html

Omondi, G., \& Juma, V. (2013, July 17). KRA targets small businesses in bid to raise Sh974 billion. Business Daily. Retrieved from http://www.businessdailyafrica.com/KRA-targets-small-businesses-in-bid-to-raise-Sh974-billion/-/539546/1918230/-/ iwuo25/-/index.html

Phelps, N. A. (2008). Cluster or capture? Manufacturing foreign direct investment, external economies and agglomeration. Regional Studies, 42(4), 457-473. doi:10.1080/00343400701543256

Ratio Magazine. (2009, June 12). Kenya: Bandwidth Subsidy for BPO Did Not Hit the Spot. Retrieved from http://www.ratiomagazine.com/20090612691/Kenya/Kenya-Bandwidth-Subsidy-for-BPO-Did-Not-Hit-the-Spot.html

Ratio Magazine. (2013, September 2). News Analysis: A Boost for the BPO/Outsourcing Industry? Retrieved from http://www. ratio-magazine.com/201309024261/News-Analysis/News-Analysis-A-Boost-for-the-BPO/Outsourcing-Industry.html

Republic of Kenya. (2007a). Vision 2030: A Globally competitive and prosperous Kenya. Nairobi: Government of Kenya.

Republic of Kenya. (2007b). Vision 2030: The popular version. Nairobi: Government of Kenya.

Saraswati, J. (2012). Dot.compradors: Power and policy in the development of the Indian software industry. London: Pluto Press.

Sheth, S. (2013, January 21). BPO for the BoP - defining impact sourcing and its potential to boost employment opportunity. Next Billion. Retrieved from http://www.nextbillion.net/blogpost.aspx?blogid=3112.

Singer, B. (2006, February 28). Kenya: Start-up views for outsourcing pie. Daily Nation. Retrieved from http://www.plex86.org/ computer_2/StartUp-Vies-for-Outsourcing-Pie-3039.html

Spence, C., \& Carter, D. (2011). Accounting for the general intellect: Immaterial labour and the social factory. Critical Perspectives on Accounting, 22(3), 304-315. doi:10.1016/j.cpa.2010.12.007

Stark, D. (2009). The sense of dissonance: Accounts of worth in economic life. Princeton: Princeton University Press.

Steinmueller, W. E. (2002). Knowledge-based economies and information and communication technologies. International Social Science Journal, 54(171), 141-153. doi:10.1111/issj.2002.54.issue-171 
Taylor, L., \& Schroeder, R. (2015). Is bigger better? The emergence of big data as a tool for international development policy. GeoJournal, 80(4), 503-518.

Taylor, P., \& Bain, P. (2008). United by a common language? Trade union responses in the UK and India to call centre offshoring. Antipode, 40(1), 131-154. doi:10.1111/anti.2008.40.issue-1

Thibodeau, P. (2012). Amid US outsourcing fears, India's IT firms thrive. Yale Global. Retrieved from http://yaleglobal.yale.edu/ content/amid-us-outsourcing-fears-indias-it-firms-thrive

Tregenna, F. (2010). How significant is intersectoral outsourcing of employment in South Africa? Industrial and Corporate Change, 19, 1427-1457. doi:10.1093/icc/dtq001

Waema, T. (2009, July). Development of a business process outsourcing industry in Kenya: Critical success factors (IDRC Final Technical Report). Retrieved from http://idl-bnc.idrc.ca/dspace/bitstream/10625/41277/1/129133.pdf

Wausi, A., Mgendi, R., \& Ngwenyi, R. (2013, August). Labour market analysis and business process outsourcing in Kenya: Poverty reduction through information and digital employment and digital employment initiative (Research Report 2013 ) 3. Retrieved from http://sds.ukzn.ac.za/files/ITEM1-researchpaper_KENYA_Aug_FINAL.pdf

Weick, K. E. (1995). Sensemaking in organizations. London: Sage.

Yi, S. (2012). Reaching the world through private sector initiative: Service exports from the Philippines. In A. G. Goswami, A. Mattoo, \& S. Saez (Eds.), Exporting services: A developing country perspective (pp. 121-159). Washington, DC: World Bank. Retrieved from https://openknowledge.worldbank.org/bitstream/handle/10986/2379/658370EPI188160Box365736B0Exporting. pdf?sequence $=1$ 